\title{
ICカードデータによる熊本市電利用者の 行動特性分析とダイヤ編成への活用
}

\author{
森田 琭雅 1 溝上 章志 2 -中村 嘉明3 \\ 1学生会員 熊本大学大学院自然科学研究科（=860-8555 熊本市黒髪2-39-1） \\ E-mail: 166d8833@st.kumamoto-u.ac.jp \\ 2正会員 熊本大学教授 大学院自然科学研究科（干860-8555 熊本市黒髪2-39-1） \\ E-mail: smizo@gpo.kumamoto-u.ac.jp \\ 3正会員＼cjkstart構造計画研究所（干869-1235 熊本県菊池郡大津町室1315） \\ E-mail: nakamuray@kke.co.jp
}

\begin{abstract}
近年，地方では公共交通利用者数の減少による事業者の赤字経営が問題となっている．また多くの利用 がある都市部の公共交通でも，渋滞緩和や乗換の待ち時間調整などの課題は尽きない。より正確で詳細な 公共交通の利用実態の把握，問題の原因発見や運行の見直しが必要とされている.

本研究では熊本市電を対象に, ICカードデータを利用して, 利用者特性分析と実績ダイヤの作成・分析 を行った, 具体的には, クラスター分析による利用者の分類と定期券購入前後での利用変動の分析, ダイ ヤ編成支援システムとの結合による実績ダイヤの作成，問題点の考察を行った.
\end{abstract}

Key Words : smart card data, Kumamoto city tram, trip behavior, cluster analysis, actual diagram

\section{1. はじめに}

以前より，日本では自動車の分担率が上昇し，公共交 通の利用者数は減少している.これにより大気污染や交 通淽滞，公共交通事業の赤字経営等，様々な社会的な問 題が発生している. 公共交通の利用減少の負のサイクル を止めるため，事業者は利用者にとって便利で定時性や 信頼性の高い公共交通サービスを提供することはもちろ ん, 需要の変動や利用特性を正確にとらえ, それに応じ た適切なサービスをいかに設計するかが求められている。 しかし長年行われている乗客のカウント調査やアンケー 卜調査では，ある特定の日のデータや，少数一部の利用 者の回答しか把握できないといった問題がある.

一方，公共交通の乗車券としての交通系ICカードの利 用は急速に進んでおり, その発行枚数, 利用可能地域は

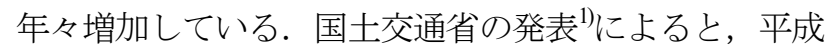
28年現在では1億枚を超えるカードが発行されており， 旅客交通サービスレベルの向上や訪日外国人旅行者 2,000万人に向けた取り組みの一環として，平成32年の東 京オリンピック開催までに全国で相互利用可能な交通系 ICカードをすべての都道府県で使えるようにするという 目標も定めている. これにより, 各鉄道会社には大量の
利用履歴データが収集, 蓄積されており, 今後もデータ 数は増加していくことが予想されている. 熊本市でも平 成26年3月に全国相互利用可能なICカード「でんでん nimoca」を熊本市電に, 平成27年4月に熊本地域振興IC カード「くまモンのIC CARD」を路線バス・電鉄電車に 導入した.

国内ではICカードは主に決済ツールとして利用されて いるだけであるが，海外を中心にICカードデータから得 られる種々の情報を交通の分析や計画に活用する研究が

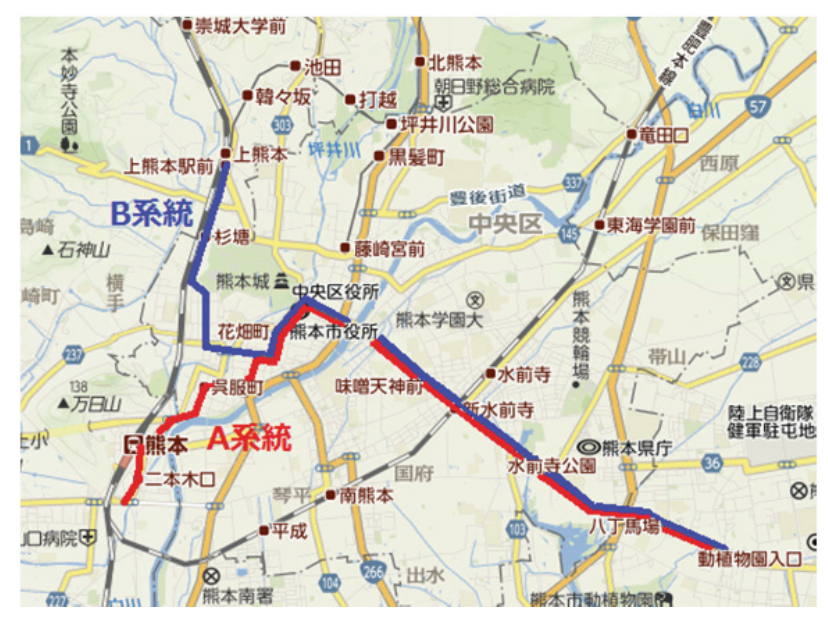

図-1 熊本市電路線図 
行われている．湧口2)が紹介しているPellertierら ${ }^{3)}$ の論文 レビューでは, 海外の研究は，1）戦略的（長期のネッ トワーク計画や需要予測など），2）戦術的（ダイヤ調整 や移動の連続的パターン分析など），3）運用（路線別の 需要・パフォーマンス指標やICカードの運用適正化に関 係する分析など）の3つのレベルに分類できること，研 究の数としては戦術的レベルのものが最も多く, その成 果が注目を集めていることを明らかにしている．国内の 研究事例としては, 西内・轟) はICカードデータから得 られる利用者の時間的・空間的利用履歴情報を用いて高 知市における路面電車・バス利用者の分類を行い, 分類 の結果得られた非定期利用者に対する利用促進施策の重 要性を提言した。松本ら ${ }^{5)}$ はICカードの移動利用データ を用いて, 静岡市におけるバス利用者の交通特性を分析 し，潜在的利用者の抽出を行い，低頻度利用者の利用促 進に繋がる基礎的な特性を抽出した.

本研究ではこれらの成果を参考にして, 市電で導入さ れている全国相互利用ICカードの利用履歴データを用い て, 市電利用実態の把握と非集計型クラスター分析によ る利用者の分類, 定期券購入による利用变動の分析を行 う。ささらに電車遅延の原因究明やダイヤ編成支援への最 初のステップとして，任意の日のデータを集計して実際 の運行ダイヤを作成し, 問題点や改善点を示すことを目 的とする.

\section{2. 利用データの概要}

\section{(1) 分析に用いるデータ}

2014年4月1日から2015年3月31日までの1年間，熊本市 交通局には全国相互利用のICカードによる約170万の処 理データが蓄積された．本研究ではこの中から ICカー ドとしての登録処理, 乗車情報のない乗降処理, エラー 処理らを除く有効乗降処理約165万サンプルを用いて分 析を行う。利用者 1 人が複数枚のカードを使用している 可能性も考えられるが, 本研究ではカード1枚のデータ を利用者 1 人のデータとして扱う. 現在は熊本県内のバ スの料金決済のために導入された地域ICカードである 「くまモンのICカード」も市電で利用可能になっている.

\section{（2）カード属性}

データ項目の「カードID」から, 全10種類の全国のIC カードが識別できるようになっている．本研究ではこれ ら10種類のカードを, 表-1のカード属性分類に示すよう に販売されている地域によってnimoca（熊本県内で販 売）, 九州圈内（熊本外の九州内で販売），九州圈外

（九州外で販売）の3つに分類した. 図-2にカード属性 毎の利用回数と利用人数を示す. 利用者 1 人あたりの年
表-1 ICカードから得られるデータの内容

\begin{tabular}{|c|c|}
\hline & 内容 \\
\hline 期間 & 2014年 4月 1日～2015年 3月 31日 \\
\hline 有効処理 & 1,707,103回 \\
\hline 有効乗降処理 & 1,652,648回 \\
\hline 出現カード枚数 & 209,494枚 \\
\hline カード属性分類 & $\begin{array}{l}\text { nimoca (nimoca)，九州圈内 (はやかけん, } \\
\text { SUGOCA)，九州 圈 外 (TOICA, Suica, }\end{array}$ \\
\hline データ項目 & $\begin{array}{l}\text { Kitaca, ICOCA, PASMO, PiTaPa, manaca) } \\
\text { カード ID, 利用日時 (分単位まで), 乗車 } \\
\text { 電停, 降車電停, 乗車人数, 車両番号, 系 } \\
\text { 統 等 }\end{array}$ \\
\hline 処理種類 & 購入, 乗降車, チャージ, 返却 等 \\
\hline
\end{tabular}

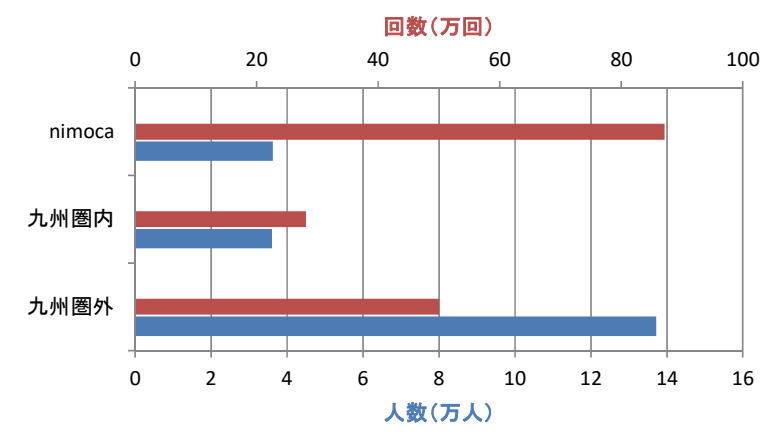

図-2 カード属性別年間の利用回数と利用人数

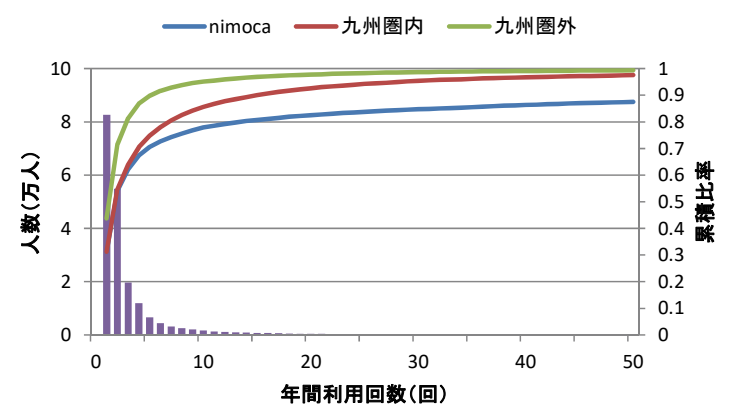

図-3 年間利用回数の分布と累積比率

表-2 カード属性別高回数利用者数

\begin{tabular}{c|rrr}
\hline 年間利用回数 & nimoca & 九州圈内 & 九州圈外 \\
\hline $201 \sim 250$ & 668 & 47 & 39 \\
$251 \sim 300$ & 326 & 21 & 29 \\
$301 \sim 350$ & 109 & 19 & 14 \\
$351 \sim 400$ & 55 & 13 & 9 \\
$401 \sim 450$ & 38 & 7 & 5 \\
$451 \sim 500$ & 12 & 4 & 4 \\
$501 \sim 550$ & 5 & 3 & 0 \\
$551 \sim 600$ & 2 & 0 & 0 \\
$601 \sim 682$ & 2 & 0 & 0 \\
\hline 総計 & 1,218 & 114 & 100 \\
\hline
\end{tabular}

間利用回数（利用回数利用人数）が最も多いのはnimoca で24.0回/人, 次が九州圈内で7.81回/人, 九州圈外は少な く, 3.64回/人であった. 九州圈外の 1 人あたりの利用回 数が少ないのは，遠方から熊本市に来た人が多く含まれ ていることに起因寸ると考えられる. 図-3は年間利用回 数50回以下の利用者の分布と各カード属性の全利用者に 対する累積比率を示している. 年間で1 2回しか利用し 


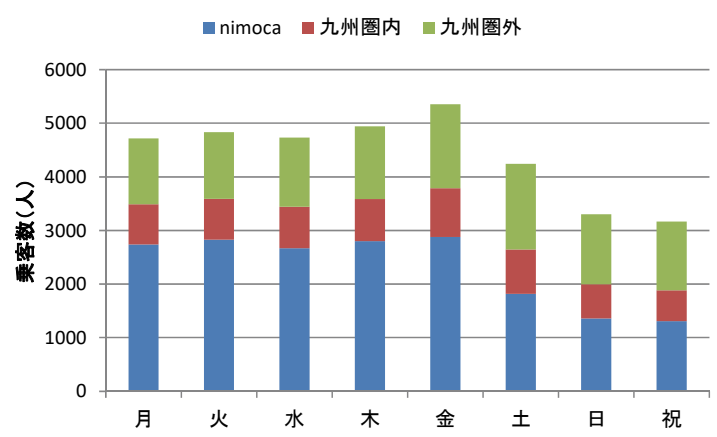

図-4 曜日別 1 日あたりの利用回数

ていない利用者は137,567人で，全体の65\%にもなり，そ のうちの約7割（98,234人）は九州圈外が占め，来訪者の 割合が多いことが明らかになった。しかし，高回数利用 者のカード属性を示寸表-2を見て分かるように，年回利 用回数が多い九州圈内・九州圈外も，少数ではあるが存 在する.これは，カード属性だけで利用者の特性，たと えば県外からの来街者であるかなどを分類することがで きないことを示している，4章ではICカードから得られ る各種の情報をもとに，利用者を属性別に分類する.

\section{(3) 曜日 - 時間帯利用回数}

図-4は年間の曜日別1日あたりの利用回数を示してい る. 土・日・祝日の利用回数は平日より減少しているが, 九州圈内や九州圈外のICカードの利用回数にはほとんど 減少はなく, nimoca利用者だけが減少していることが分 かる.

図-5，図-6は平日と休日の時間帯別カード属性別の利 用者数の比率を示している. 平日では, nimocaによる7 時〜9時頃に短時間の高密度な朝ピークが，16時〜20時 頃にも比較的長時間の低密度な夕方ピークが見られる. また，夕方ピーク時間帯には16時頃の学生の下校による ピークと18時頃の社会人の帰宅によるピークがあること， 休日については, nimocaによる朝ピークが若干見られる ものの, 九州圈内, 九州圈外カードと同様に，1日を通 して時間的に大きな変動がなく利用されていることが分 かる. 休日の市電利用者数减少やいくつかのピークの存 在は従来より感覚的に分かっていたが，ICカードデータ の分析により, 客観的に明らかになった.

\section{ICカードデータの信頼性}

\section{（1）電停間乗降客数の推計値の精度}

熊本市電での運賃の支払い方法は現金による支払いや 運転手一の乗車券等の提示といったものもあることから， ICカードによる決済から得られるデータはサンプルデー タである，そのため，真の利用実績とICカードから得ら

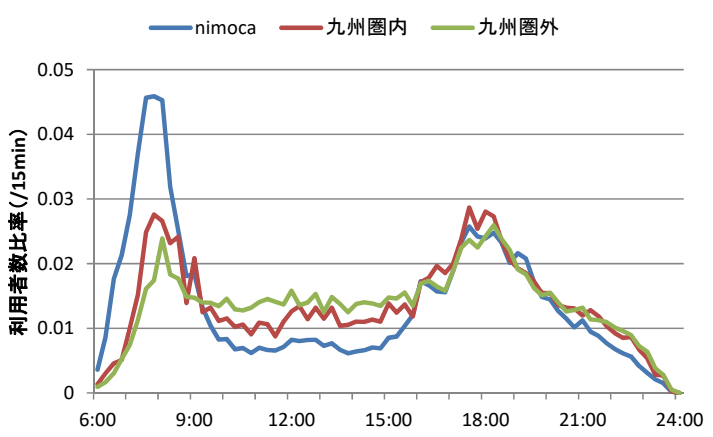

図-5 平日の時間帯別カード属性別利用者数の比率

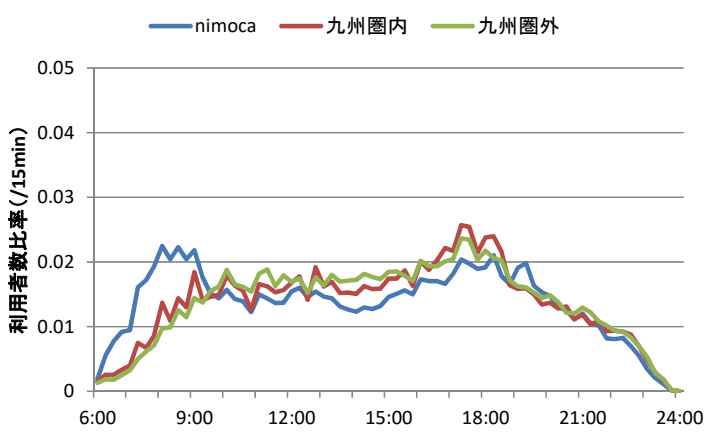

図-6 休日の時間帯別カード属性別利用者数の比率

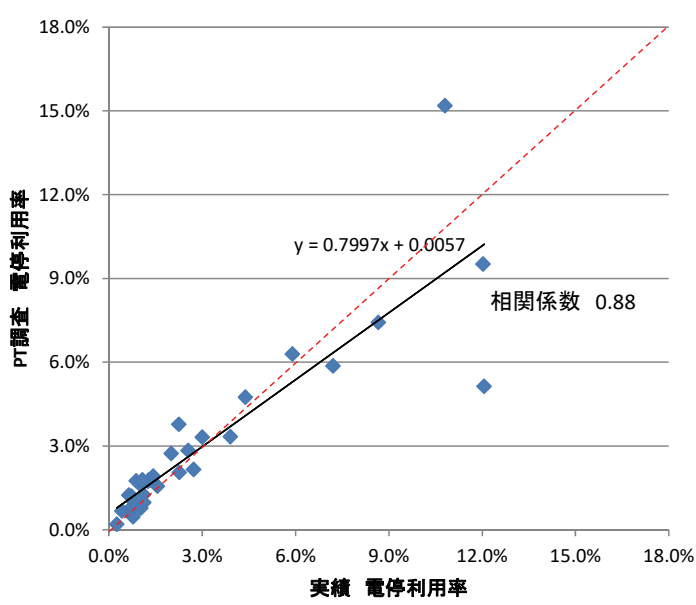

図-7＼cjkstart電停利用率の実績と PT 調査データからの 集計值との比較

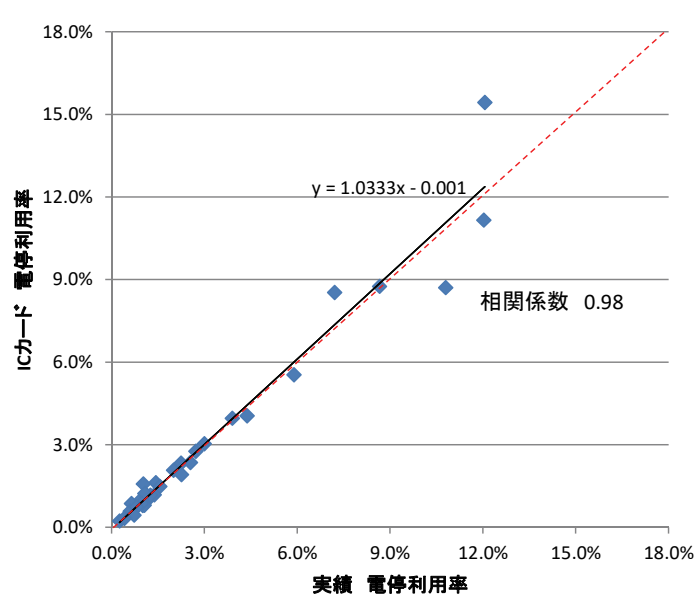

図-8 電停利用率の実績と IC カードからの 推計值との比較 
れる限定的な情報との違いをあらかじめ把握しておく必 要がある. ここでは, 熊本市交通局が毎年実施している 市電乗降調査を基に, 実際の電停間乗客数を推計し, こ れを真值として，ICカードデータから得られる電停間乗 客数の推計值の信頼性について検討する. 参考のために, 第4回熊本都市圈パーソントリップ調査（以下PT調査と 記す）からの推計值の信頼性との比較も行った.

まず，熊本市交通局によって2014年10月の平日に実施 された全数調查である停留所別乗降人員計数データと約 20\%抽出の路線別電停間乗客数調査デー夕をもとに, 前 者の電停別乗降者数に一致するようにフレーター法を用 いて後者の路線別電停間乗客数調査データを修正・拡大 することによって, 路線別電停間乗客数を推計し, これ を真值と仮定する.

市電の電停間乗客数は, PT調査から得られる市電利 用トリップを電停間で集計し，拡大率によって拡大寸る ことで求めることもできる．しかし，PT調査は公共交 通機関利用者のサンプル数が少ないために, 真值との差 が大きいことが指摘されている．これに対して，ICカー ドのデータはPT調査データよりもサンプル数が飛躍的 に増大寸るために，より実績に近い電停間乗客数を推計 できると考えられる.

図-7と図-8は，前節で推計した電停間乗客数から得ら れる電停利用率に対して，それぞれPT調査データと IC カードデータから推計された全 35 電停の電停利用率の分 布を示している. 電停利用率とは, 電停別の乗車人数と 降車人数の平均の全市電利用者数に対する比である.

PT調查を先験とした場合は，電停利用率の相関係数は
0.88で相関は高いものの，線形近似直線を見てみると実 績利用率が低い電停で過大に, 高い電停で過小に推計さ れていることが分かる.これに対して，ICカードを先験 とした場合では, 相関係数は 0.98 と, 非常に強い相関と なる. 近似直線を見ても再現性が高いことが分かる.ま た, それぞれの電停利用率の差からF検定を行うと， F 值は4.37となり， 2つの分布には有意な差があった. よ って, PT調査データよりもICカードデータを先験とし て推計した電停利用率の方が信頼性は高いといえる.

\section{（2）誤差とICカードの利用率}

10月の平日の寸べてのICカード利用データから得られ る, 平日1日あたりの電停間利用者数の平均值を分子に, 前節で求めたODの実績值を分母にし, 各OD間のICカー ド利用率を表したものが図-9である，ただし信頼性が低 いデータを除くため, 実績利用者数が10人に満たない電 停間のデータは除いている.

全利用者数に対するICカードの利用率は約 $15.6 \%$ であ り, 決して利用率は高いとは言えない.これは予想より かなり低い值であったが，月日が経つにつれてカードの 処理回数は増えており，2015年3月には2014年10月の約 1.7倍のデータが収集された. 今後も, ICカードの利用 率はさらに増加することが期待できる.

\section{4. 利用者の行動特性}

IC カード 1 枚ごとにデータを集計することで，利用

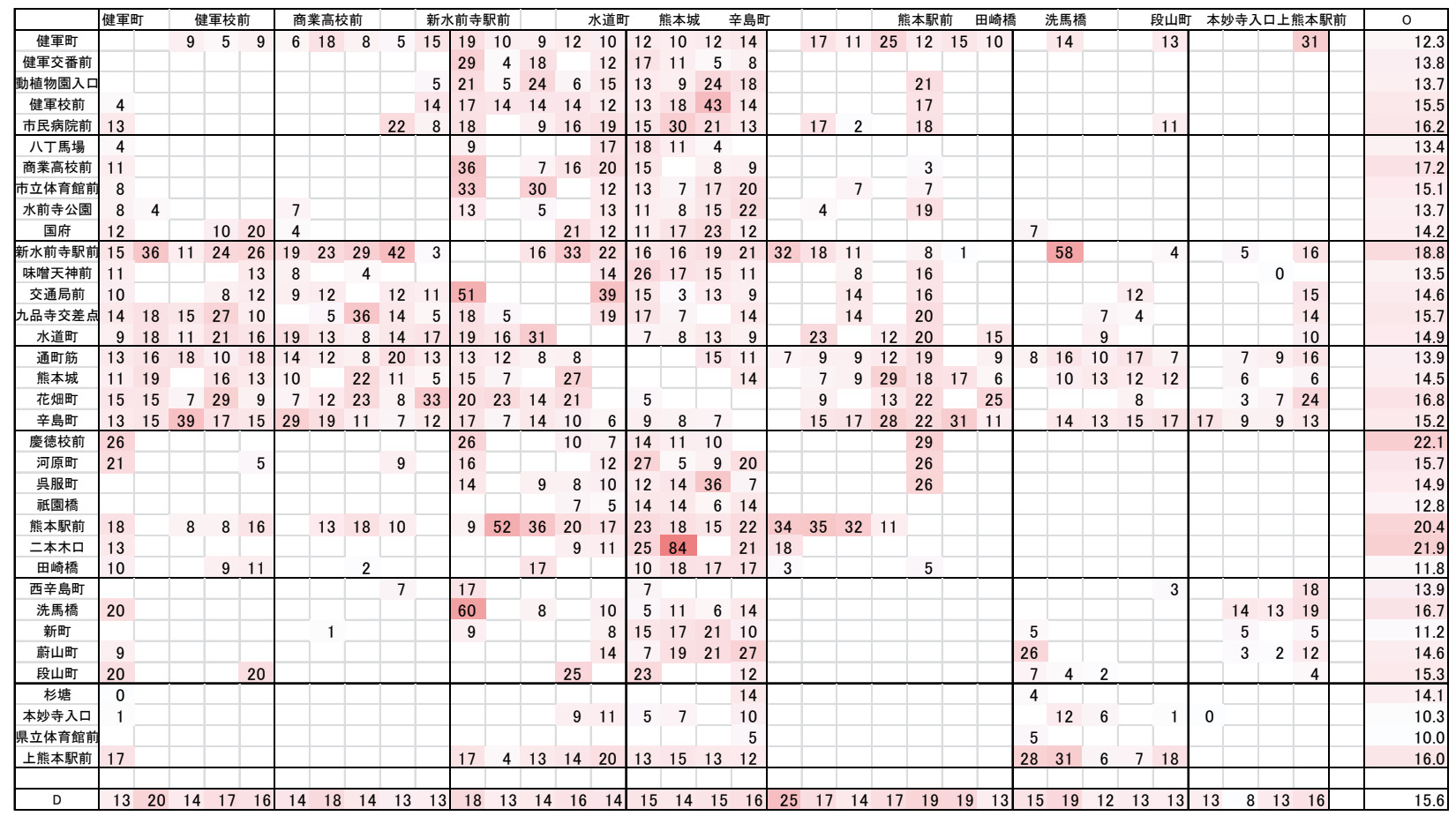

図-9＼cjkstart電停間毎のICカード利用率（\%) 
者の利用特性や利用変動を分析することができる．本章 では, クラスター分析による利用者の分類と定期券サ一 ビス開始による利用回数の変化についての分析を行った.

\section{(1) クラスター分析による利用者分類}

特別な連休のない2015年2月1日〜2015年2月28日の4週 間の期間に乗車した35,670人の利用者を行動特性によっ て分類することを目的として，表-3を変数とした非階層 的クラスター分析を行った. 変数は時間的特性のみ採用 しているが，空間的特性も考慮することが望ましい，こ れは今後の課題としたい. また，今回はクラスター数を システマティックに決めるためにGap統計量を用いた.

図-10に示寸結果より，できるだけ多くのクラスターに 分類し, かつ各クラスターの詳細な特徵を分析するため, それまでは連続的に減少しているGap統計量が再び増加 するクラスターの最小の数である $k=6$ を採用し, 非階層 的クラスタリングを行った．表-4は各クラスターに属す る利用者の人数とクラスター毎の各変数の平均值を示し

表-3 クラスター分析の変数

\begin{tabular}{c|c}
\hline 変数 & 説明 \\
\hline カード属性 & 全国相互利用のカードの種類 \\
利用回数 & 期間中の乗車回数 \\
平日利用率 & 平日 1日あたりの利用回数 \\
休日利用率 & 休日 1 日あたりの利用回数 \\
朝ピーク利用率 & 平日 7:00〜9:00の利用率 \\
タ方ピーク利用率 & 平日 16:00〜20:00の利用率 \\
\hline
\end{tabular}

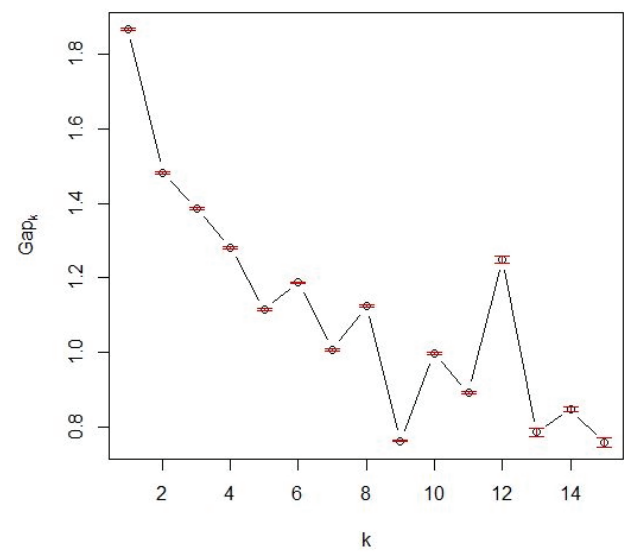

ている

クラスター毎の特徵を表-5にまとめ, それぞれのクラ スターに属する利用者特性について考察できることを述 ベる.

クラスター1: カード属性ではnimocaが大半を占め, 利 用回数，平日利用率だけでなく休日利用率も最大であり， 朝ピーク利用率と夕方ピーク利用率もある程度大きな值 を示している. 平日の通勤, 通学の利用と共に, 休日の 利用も多い定期的な日常利用者であると考えられる.

クラスター2: 半数以上が九州圈外であり利用回数は 1.78回である. 夕方ピーク利用率が 0.95 と非常に高く, 数回の利用がほとんど夕方ピークの時間に該当した利用 者で，月に数度夕方に利用している利用者である.

クラスター3: 九州圈外のみで構成されており, 利用回 数も2.34回と低いことから, 対象期間中の九州圈外から の来訪者と考えられる.

クラスター4 : nimocaと九州圈内のみで構成されている が, 利用回数は3.13回にとどまっている. 通勤, 通学で は利用していないが，時々利用する熊本市内在住の利用 者と，対象期間中に熊本市を訪れた九州圈内に在住の来 訪者と考えられる.

クラスター5 : クラスター1に良く似ているが，休日利用

表-5 各クラスターにおける行動特性

\begin{tabular}{|c|c|c|}
\hline クラスター & $\begin{array}{c}\text { 該当者数 } \\
\text { 構成比 }\end{array}$ & 特徵 \\
\hline 1 & $\begin{array}{l}1,325 \text { 人 } \\
3.71 \%\end{array}$ & $\begin{array}{l}\text { 平日休日共に高頻度で利用してい } \\
\text { る. 休日も通学・通勤をしている } \\
\text { か, 通勤・通学以外でも利用. } \\
\end{array}$ \\
\hline 2 & $\begin{array}{l}7,138 \text { 人 } \\
19.96 \%\end{array}$ & $\begin{array}{l}\text { 数回の利用はほぼ夕方ピーク時. 毎 } \\
\text { 回ラッシュや遅延に乗り合わせてい } \\
\text { る可能性が高い. }\end{array}$ \\
\hline 3 & $\begin{array}{l}12,226 \text { 人 } \\
34.19 \%\end{array}$ & $\begin{array}{l}\text { 九州圈外からの熊本来訪者. 朝ピー } \\
\text { ク時と夕方ピーク時には利用してい } \\
\text { ない. }\end{array}$ \\
\hline 4 & $\begin{array}{c}10,277 \text { 人 } \\
28.74 \%\end{array}$ & $\begin{array}{l}\text { 対象期間に利用した熊本県内・九州 } \\
\text { 圈内に在住の利用者. 朝ピーク時の } \\
\text { 利用はほとんどない. }\end{array}$ \\
\hline 5 & $\begin{array}{c}2,101 \text { 人 } \\
5.88 \%\end{array}$ & $\begin{array}{l}\text { 平日は高頻度で利用. 休日の利用も } \\
\text { あるがほとんどは平日の通勤・通学 } \\
\text { での利用. }\end{array}$ \\
\hline 6 & $\begin{array}{c}2,693 \text { 人 } \\
7.53 \%\end{array}$ & $\begin{array}{l}\text { 数日の利用があり, 多くが朝ピーク } \\
\text { 時に利用. 夕方ピーク時の利用はほ } \\
\text { とんどない. }\end{array}$ \\
\hline
\end{tabular}

図-10 Gap 統計量

表-4 クラスター分析の結果

\begin{tabular}{|c|c|c|c|c|c|c|}
\hline & \multicolumn{6}{|c|}{ クラスター } \\
\hline & 1 & 2 & 3 & 4 & 5 & 6 \\
\hline 該当者数 & 1,325 & 7,138 & 12,226 & 10,277 & 2,101 & 2,693 \\
\hline nimoca & 1,240 & 1,022 & 0 & 4,862 & 1,892 & 551 \\
\hline 九州圈内 & 40 & 1,831 & 0 & 5,415 & 124 & 607 \\
\hline 九州圈外 & 45 & 4,285 & 12,226 & 0 & 85 & 1,535 \\
\hline 利用回数 & 43.53 & 1.78 & 2.34 & 3.13 & 32.66 & 3.20 \\
\hline 平日利用率 & 1.65 & 0.06 & 0.08 & 0.11 & 1.56 & 0.13 \\
\hline 休日利用率 & 1.36 & 0.06 & 0.09 & 0.11 & 0.32 & 0.07 \\
\hline 朝ピーク利用率 & 0.23 & 0.01 & 0.01 & 0.02 & 0.36 & 0.71 \\
\hline 夕方ピーク利用率 & 0.29 & 0.95 & 0.14 & 0.18 & 0.32 & 0.13 \\
\hline
\end{tabular}


率が低くなっている．さらに朝ピーク利用率・タ方ピー ク利用率はクラスター1に比べて大きくなっている. 特 に通勤，通学での定期的な利用しているが，休日はあま り利用していない日常利用者であると考えられる.

クラスター6: カード属性の割合がばらけており, 利用 回数は3.20回である. 朝ピーク利用率が 0.71 と高く, 月 に数度朝のラッシュ時に乗車する利用者であり, 通勤ピ 一クに乗り合わせる可能性が高い.

\section{（2）定期券サービスの開始による行動変動}

でんでんnimocaには2014年10月以降，定額料金の前払 いで市電のどの区間にも乗り放題の定期券機能をつける ことが可能になった. このサービスの利用によって生じ た利用者の行動変化の分析として，平日，休日別に利用 率の変化を分析する.

2015年10月1日～2015年10月31日の1ヶ月間に, 利用中 のでんでんnimocaカードに定期券機能を追加した利用者 190 人を対象に，定期券購入日から前後1ヶ月間ずつの平 日，休日の1日あたりの利用回数の変動数の分布を図-11 に示寸. 平日, 休日の利用頻度について, 1.0回/日を境 に, それ以上を高頻度, 以下を低頻度と仮定し, タイプ $\mathrm{A}$ : 平日低頻度・休日低頻度, タイプB : 平日高頻度・ 休日低頻度, タイプC : 平日低頻度・休日高頻度, タイ プD : 平日高頻度・休日高頻度の4種類に分類した。

図-11では各利用者の定期券購入前のタイプ別に分布 の色とマークを変えている. 全体の利用回数は平日平均 が1.25回/日, 休日平均が0.61回/日増加した. タイプAで あった利用者は，平日平均が1.40回/日，休日平均が 0.68 回/日増加した。 このタイプの利用者は, 通勤, 通学に 市電を利用していなかった低頻度の利用者であると考え られるが，定期券を購入したことによって，平日の通勤， 通学での市電利用が増えたり, 休日の仕事や外出にも市 電を利用するようになったことが考えられる.タイプB であった利用者は，平日平均が 0.18 回/日，休日平均が 0.12回の増加にとどまった. このタイプは以前から平日 に高頻度で利用しており，休日の利用頻度が少なかった グループであり，定期券購入によって休日にも市電を利 用するようになるということも容易に想像できたが，一 概にそうとは言えないことが分かった。 タイプCであっ た利用者は，今回存在しなかった．タイプDであった利 用者は 5 人のみで, 平日平均が 0.20 回/日，休日平均は 0.11 回/日のみ増加した．このタイプの利用者は, 定期券購 入前から平日，休日ともに高頻度で利用していた利用者 であるため, 大きな変化は見られない，

定期券購入前後の各タイプの人数の推移を表-6に示す. タイプ $\mathrm{A}$ は 147 人減少, タイプ $\mathrm{B} は 96$ 人増加, タイプ $\mathrm{C}$ 人から 7 人に増加，タイプ Dは44人増加した．定期券購 入後, 休日高頻度であるタイプCとタイプDになった利

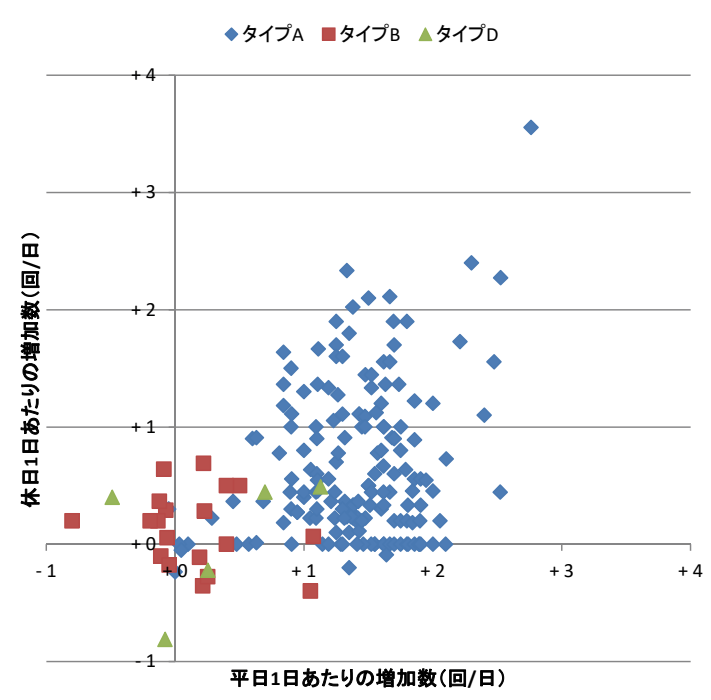

図-11 定期券購入者の購入前後の利用回数変化

表-6 定期券購入前後の各タイプの人数変動

\begin{tabular}{|c|c|c|c|c|c|c|}
\hline & \multicolumn{5}{|c|}{ 購入後 } \\
\hline & & A & B & $\mathrm{C}$ & D & 合計 \\
\hline \multirow{5}{*}{$\begin{array}{l}\text { 購 } \\
\text { 入 } \\
\text { 前 }\end{array}$} & A & 18 & 97 & 6 & 45 & 166 \\
\hline & B & 1 & 17 & 0 & 1 & 19 \\
\hline & $\mathrm{C}$ & 0 & 0 & 0 & 0 & 0 \\
\hline & D & 0 & 1 & 1 & 3 & 5 \\
\hline & 合計 & 19 & 115 & 7 & 49 & 190 \\
\hline
\end{tabular}

用者の $91 \%$ （51人 $/ 56$ 人） が定期券購入前にタイプAであ った利用者であることから，定期券サービスの効果によ って休日の利用回数が増加したといえるのは, その大半 が通勤・通学に市電を利用していなかった利用者（タイ プA）であることが分かった.

\section{ICカードデータによる運行・需要の分析可能性}

\section{(1) ICカードデータによる問題の分析}

バスロケーションシステムから得られる各車両の位置 データがあれば，遅延や渋滞がいつどこで起こっている のかといった運行に関する分析は可能であるが，乗降客 数などの利用実態データと組み合わせない限り, 遅延の 原因などの分析はできないので, 適切なダイヤ再編のた めの基礎データとしては使えない. 一方，IC カードデ 一タからは，電停ごとの最早の乗車時刻，または降車時 刻を到着時刻, 最遅の乗車, または降車時刻を出発時刻 と仮定することによって, 車両の移動軌跡の追跡が可能 になる．また，時刻表上の到着時刻と実績到着時刻との 差である遅延時間, 電停での出発時刻と到着時刻の差で ある停車時間, 電停ごとの（全数ではなく, 決済数に比 
例した）乗降人数，連続した電停間の乗客数などの情報 が容易に算出できる.このように，運行だけでなく利用 の実態を詳細に把握することができることから，運行と 利用の相互関係を分析寸ることも可能である. なお，IC カード利用者の乗車・降車がない電停では通過時刻が不 明となる. このような場合, 図-12 を例に，以下のよう にして通過時刻を推定した。 もし，電停 B における通 過時刻が不明の場合， $\mathrm{AC}$ 間実測所要時間（10 分）に $\mathrm{AB}$ 間時刻表所要時間 $/ \mathrm{AC}$ 間時刻表所要時間 (2/5) を乗 じたもの（4分）を $\mathrm{AB}$ 間所要時間とし，それを $\mathrm{A}$ 出発 時刻に加算したもの（9:04）を B の到着時刻および出発 時刻とする.

本研究ではその検討例として, ICカードの乗降時刻デ 一タから実際の運行状況を観測して時刻表ダイヤに重称 ることで，実際の運行状況の可視化，乗客の数と電車の

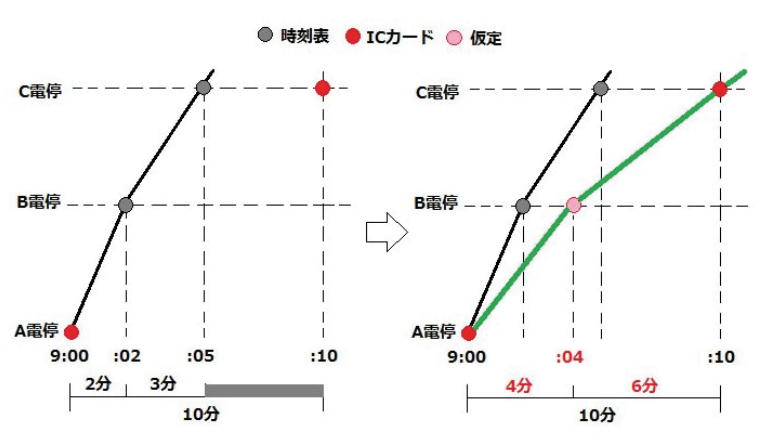

図-12 電停の通過時刻の算出方法

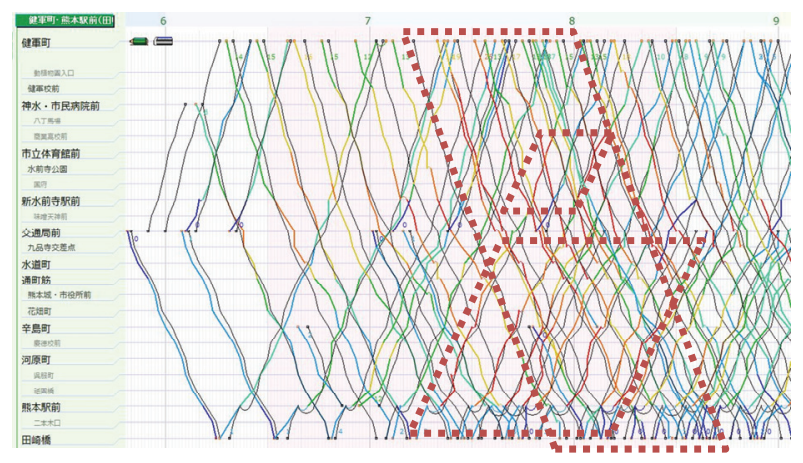

図-15 2015年 2 月 19 日（木） 6:00-9:00の乗車人数

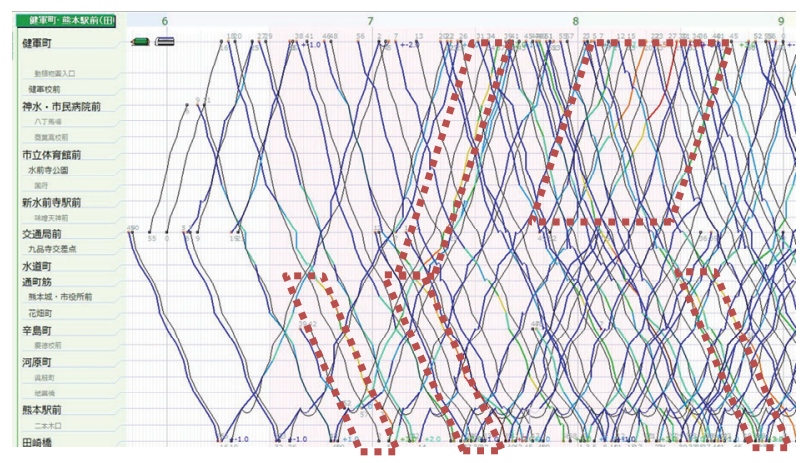

図-16 2015年2月 19 日（木）6:00 9:00 の遅延時間
遅延の関係の分析などを行い，これまでは発見できなか った熊本市電の運行上の課題の発見と今後の課題解決の ための提言を試みた。

\section{（2）運行と利用実績の分析}

バス・鉄道の運行ダイヤを作成するダイヤ編成支援シ ステムは, 数多くの会社によって製作, 販売, 運用が行 われている. 本研究では, 今回必要な実際の運行実態を 時刻表ダイヤに重ねる機能を持つフリーのダイヤ編成支 援システム「その筋屋」を使用して可視化し，以後の分 析を行う. 実際の運行状況をダイヤで示した実績ダイヤ は図-13，図-14に示すように，乗客が多いほど，遅延が 長いほど暖色を示すように設定している.

ここでは2015年2月19日（木）のA系統上下線の朝と夜 の計6時間の実績ダイヤを可視化し分析を行う。この日 の天候は午前中が曇り時々晴れ，午後は晴れ，最高気温

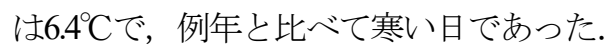

図-15は6:00 9:00の乗車人数を, 図-16は同時間帯の遅

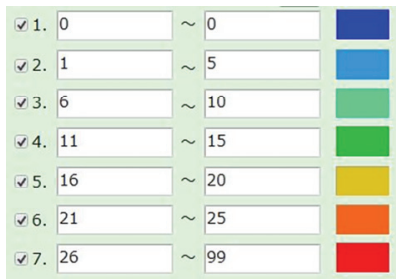

図-13 乗車人数の配色(人)

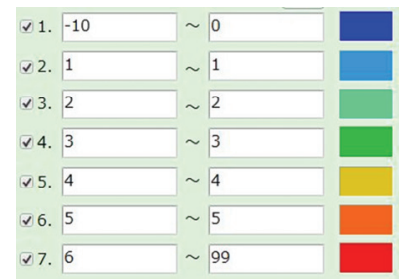

図-14 遅延時間の配色(分)

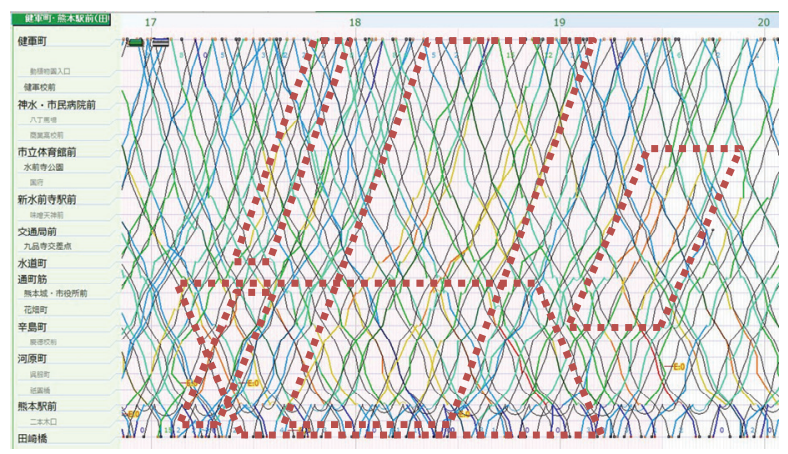

図-17 2015年 2 月 19 日（木） 17:00 20:00 の乗車人数

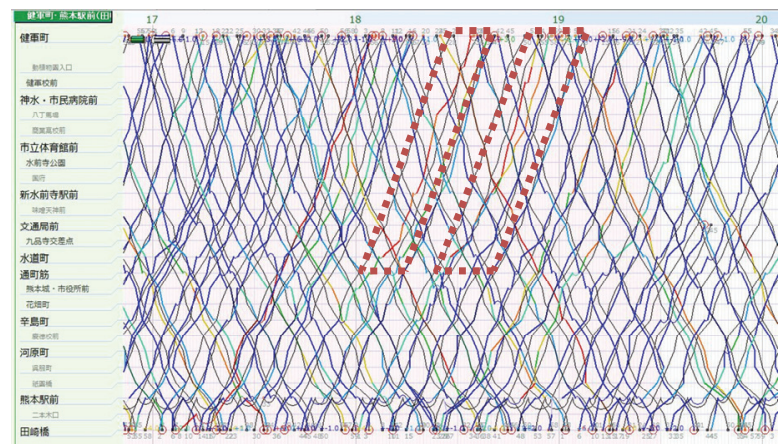

図-18２015年2月 19 日（木） 17:00 20:00の遅延時間 
延時間を示している.7:20頃から，上り路線では熊本駅 〜九品寺交差点辺りと新水前寺駅前～商業高校前辺りで 下り路線では健軍町〜通町筋辺りで, 乗客数の増加によ る朝の通勤・通学ラッシュが確認でき, どの電車も多く の客が乗車していることがわかる. しかし，遅れ時間を 見ると, 朝の時間では7便の電車にのみ, 大きな遅延が 起こっていた. 上り路線では7:15 7:35頃の水道町〜健軍 町区間と8:00 8:45頃の新水前寺〜健軍町区間で計4便, 下り路線では6:40 7:05頃と 7:00 7:30頃と 8:30 9:00頃の通 町筋〜二本木口区間で計3便で大きな遅延があった。 こ の時間帯の7便の遅延はいずれも乗客数が少ない区間で 起こっている. 朝の電車の遅延は, 乗客数の増加から起 こるのではなく, 道路混雑や信号による遅れの影響が大 きいことを示唆している.

図-17は17:00 20:00の乗車人数を，図-18は17:00 20:00の 遅延時間を示している. 夕方の時間帯では, 朝に比べて 長時間にわたって乗客が中密度の車両が多いことがわか る. その中でも, 上り路線では17:15 17:30頃の熊本駅〜 熊本城・市役所前辺りと17:30 17:45頃の九品寺交差点〜 健軍町辺り, 17:45 19:00 頃の熊本駅〜健軍町と 19:15 19:50頃の花畑町〜市立体育館前辺りで乗客が多く, 下り路線では17:15 20:00頃までの通町筋〜熊本駅までの 区間で多くの車両が中密度の乗客で運行している，また 図-18をみると，遅延がほとんどなかったこの日の夕方

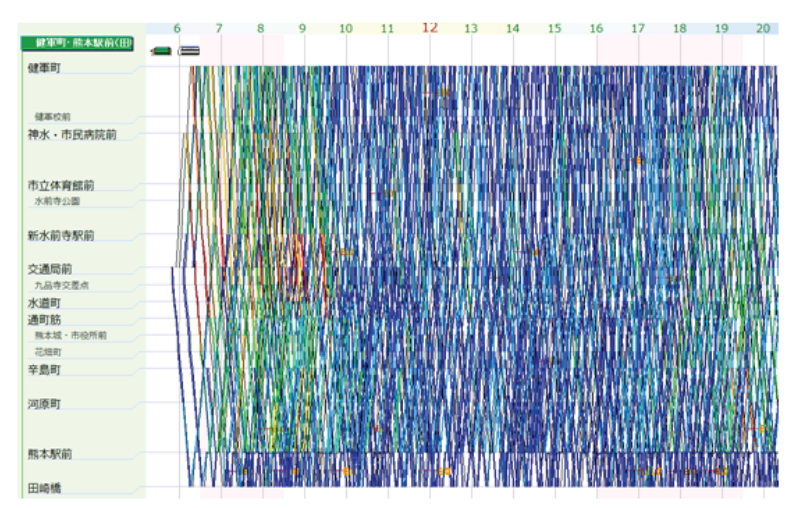

図-19 クラスター1（日常利用者）の利用実績

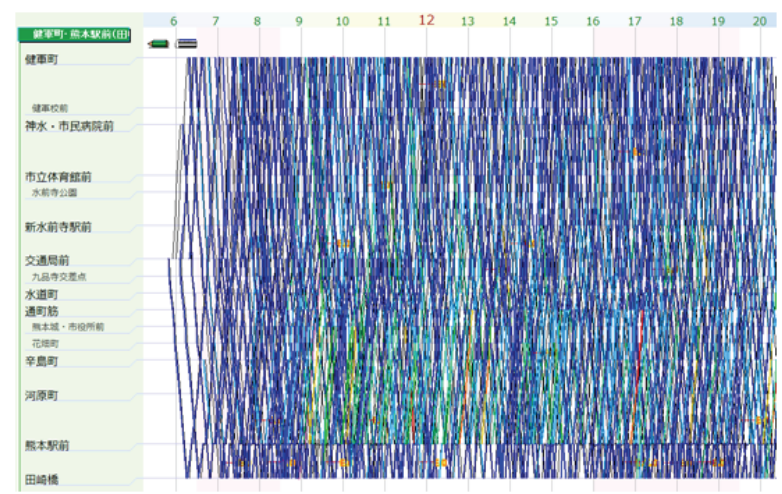

図-20 クラスター3 (来訪者) の利用実績
の時間帯において，上り路線の水道町〜健軍町の区間に おける18:10 18:35頃と 18:30 18:55頃と 18:35 18:55頃に大き な遅延を引き起こした 3 便がある. この内の2便について は, 水道町での乗客の急激な増加と水道町〜九品寺交差 点区間の速度低下に起因していることが分かる．また， 18:30 18:55頃のもう1便については，大きな遅延をした 前の車両を追従することによって発生する遅延であるこ とも読み取れる.

\section{（3）運行と利用との詳細な関係分析}

ICカードデータから算出可能な種々の情報によって運 行と需要との相互関係の分析が可能となる.ここではそ の一例を示したい.

4章で行ったクラスター分析による利用者の分類分け の結果を反映して, クラスターごとに外来者や日常利用 者などと定義し, 電車毎の外来者数や日常利用者数のば らつきを可視化することを試みた．図-19はクラスター1

（日常利用者），図-20はクラスター3（来訪者）だけを 抽出したものである. それぞれのクラスターに属する利 用者が乗車している暖色系のクラスター1では8時〜 9時 台と19時以降，クラスター3では9時以降17時頃までと， 利用を示す暖色系のスジ (電車) の時間帯が異なる.こ れらの情報より，たとえば来訪者がよく利用する時間帯 には来訪者向けの車両やアナウンスサービスなどを提供 するなどの運行計画策定のための情報として活用可能で ある。

その他，年間の運行実績データを重ねることで，スジ 1本ごとに各電停での遅延時間のばらつきが可視化でき ることから, スジ1本 (電車) ごとのダイヤの評価, 設 定された時刻表の問題点の発見, さらにはダイヤ編成一 の活用も期待できる.

\section{6. おわりに}

本研究では熊本市電を対象に, まずICカードデータが 実際の利用状況を再現するツールとしてふさわしいこと をPT調査データと比較することで示し，このデータか ら利用実態の分析及び利用者の特性分析, さらに実績ダ イヤの可視化による運行分析を行い, 問題点の考察を行 った.

本研究の分析で明らかになったことと今後の課題を以 下にまとめる.

1）乗降数カウント調査を基に実際の電停間ODを推計し て，PT調查データ，ICカードデータそれぞれと比較し た結果, ICカードデータの方が現実の再現性が高いこと を明らかにした。

2） 2014年10月の時点での乗客のICカード利用率は約 
15.6\%で，月日が経つごとに増加していると考えられる が，電停間毎に大きなばらつきがあり，拡大するにはそ れを加味する必要があり, 困難である.

3）カードの販売場所による分類で，利用回数などの大 まかな特徵を捉えることができるが，それだけで利用者 の利用特性を説明するには問題がある.

4）10月からの定期券サービスの開始によって， nimoca の利用者数, 1人あたりの利用回数は急激に増加したと 考えられる．また，5月，8月，3月には大型連休の影響 と考えられる来街者の増加が観測された.

5）市電の利用者数は平日では金曜日が最も多く，月曜 日が最も少ない．休日になると利用者数は大きく減少す るが，これは熊本市に住む人の利用減少による影響であ ると考えられる.

6）市電の朝ピークは7時〜9時頃に短時間高密度で，夕 方ピークは16時〜20時頃に長時間低密度で起こつており， それぞれ異なる対応が必要であると考えられる。 また,

夕方のピーク時間中17時前後で一時的な利用者数の減少 が起こっている.

7）市電利用者を利用特性別に6つに分類すると，高頻度 利用者が $2 つ に ，$ 低頻度利用者が4つに分類され，それぞ れの特徵を捉えることができた.

8）10月に定期券購入した利用者は，平均で平日 1.25 回/ 日，休日0.61回/日利用頻度が増加した。また，休日の利 用頻度が大きく増加した利用者は, 大半が通勤, 通学で 市電を利用していなかった利用者である.

9）実績ダイヤ図の可視化から分析を行い，各時間帯の 電車の早発や, 前を走る電車の遅れによる団子運行, 電 車の到着遅れによる次の運行始発の遅れなどの問題がい つどこで起こっているかの分析を行った.

10）今の可視化システムでは, ICカード利用者の乗車・
降車がなかった電停での電停通過の時刻データがないた め, 所要時間を仮定して可視化するしか方法がなく, こ れを改善する必要がある。

11）可視化による時刻表の問題発見には，数日間の調査 データを重ねて可視化する機能が必要であり，これがで きることでダイヤ編成への活用の可能性が拡大する.

謝辞 : 著者らの依頼に応じて機能向上をしていただいた フリーのダイヤ編成支援システム「その筋屋」の製作者， およびICカードデータを提供していただいた熊本市交通 局には，この場を借りて深く御礼申し上げます.

\section{参考文献}

1) 国土交通省：交通系ICカードの普及・利便性拡大に 向けた取組，2015.

2) 湧口清隆 : 交通分野の電子カード・データの活用方 法：世界各地の事例から, 運輸政策研究, Vol. 14, No. 2, pp. 48-49, 2011.

3) Pellertier, M., Trépanier, M. and Morency, C.: Smart card data use in public transit: A literature review, Transportation Research Part C, Vol. 19, pp. 557-568, 2011.

4)西内裕晶, 轟朝幸 : 交通マーケティング手法検討の ためのICカードデータを活用した利用者行動特性の 把握, 土木学会論文集F3(土木情報学), Vol. 68, No. 2, pp. II_8-II_17, 2012.

5) 松本浩和, 石神孝裕, 石井良治, 原田知可子, 牧村 和彦, 岩本武範 : 交通系ICカードデータを用いたバ スの潜在的利用者の抽出方法の検討, 土木計画学研 究・講演集(CD-ROM), Vol. 51, No. 17, 2015.

6) 熊本市交通局HP，http://www.kotsu-kumamoto.jp/

7) えきから時刻表, http://www.ekikara.jp/top.htm

8）国土交通省気象庁「過去の気象データ検索」, http://www.data.jma.go.jp/obd/stats/etrn/index.php?sess= $6 \mathrm{ef} 525 \mathrm{a} 9 \mathrm{cdef} 28 \mathrm{cea} 634 \mathrm{ce} 58 \mathrm{ca} 736 \mathrm{e} 68$

\section{ANALYSIS OF TRAM USERS’ BEHAVIOR AND EVALUATION OF OPERATION BY USING SMART CARD DATA}

\section{Takumasa MORITA, Shoshi MIZOKAMI and Yoshiaki NAKAMURA}

Use of the smart card when getting on public transportation, is increasing. Therefore a great deal of data is accumulated. The study which analyze using these data is receiving a lot of attention. There are many analysis of the public transportation users' behavior all over the world. In this study, I use smart card data in Kumamoto tram. The purpose of this study is three. The first one is an analysis of the actual use state. The second one is an analysis of the characteristic of user. The third one is analysis of the visualization of actual diagram. 